\title{
The Case for Commemoration Controversies in Canadian History Education
}

\author{
Lindsay Gibson \\ University of British Columbia
}

\begin{abstract}
Commemorations are events or actions that honour and memorialize significant events, people, and groups from the past. In recent years there have been numerous contentious debates about commemorations of historical events and people in countries around the world, including Canada. In this article I argue that commemoration controversies should be an essential part of teaching and learning history in $\mathrm{K}-12$ schools because they have the potential to be meaningful and relevant for students, they address civic education competencies central to history and social studies curricula in Canada, and they provide rich opportunities for advancing students' historical consciousness and historical thinking. In the final section of the article I describe how six second-order historical thinking concepts can be used to invite students to think historically about commemorations.
\end{abstract}

Canadian Journal of Education / Revue canadienne de l'éducation 44:2 (2021)

(C)2021 Canadian Society for the Study of Education/ Société canadienne pour l'étude de l'éducation 
Keywords: historical commemorations, public history, history teaching and learning, citizenship education, history education, historical consciousness, historical thinking, social studies education

\section{Résumé}

Les commémorations sont des événements ou des actions qui honorent et célèbrent des événements, des personnes et des groupes importants du passé. Ces dernières années, de nombreuses controverses et débats ont eu lieu concernant la commémoration d'événements et de personnes historiques dans de nombreux pays, dont le Canada. Dans cet article, je suggère que les controverses portant sur les commémorations devraient constituer une partie essentielle de l'enseignement et de l'apprentissage de l'histoire dans les écoles de la maternelle à la 12e année. Celles-ci ont le potentiel d'être révélatrices et pertinentes pour les élèves, elles abordent les compétences d'éducation citoyenne qui sont au cœur des programmes d'histoire et de sciences sociales au Canada et offrent de riches possibilités pour faire progresser la conscience et la réflexion historiques des élèves. Dans la dernière partie de l'article, je décris comment les six concepts de la pensée historique peuvent être utilisés pour inviter les élèves à réfléchir à l'histoire des commémorations.

Mots-clés : commémorations historiques, histoire publique, enseignement et apprentissage de l'histoire, éducation à la citoyenneté, cours d'histoire, conscientisation historique, réflexion sur l'histoire, enseignement des études sociales 


\section{Introduction}

In the last five years there have been frequent heated debates about commemorations of historical events and people in many countries around the world, including the United States, Australia, the United Kingdom, and Canada. These clashes can be viewed as another chapter in the "history wars," divisive and partisan contests over national memory, political values, and historical perspectives that often focus on history textbooks and curriculum, museum exhibits, and public commemorations (Clark \& Grever, 2018). Commemorations are events or actions that honour and memorialize significant events, people, and groups from the past. There are many types of commemorations, including public celebrations and holidays; statues, plaques, and monuments; historical sites; flags; public art; names of public institutions, buildings, towns, roads, bridges, and geographic phenomena; images and symbols on money; names of awards and prizes; and sports team names and mascots. In Canada, controversies about commemorations have focused on anniversaries of historical events like Canada 150, the sesquicentennial anniversary of Canadian Confederation, and also what Pierre Nora (Nora \& Kritzman, 1996) refers to as "lieux de memoire," or sites of memory such as statues and monuments, and the naming of public buildings, institutions, and infrastructure. For example, there have been intense debates about the removal of statues commemorating prominent historical figures, including statues of Sir John A. Macdonald in Victoria, Sir Matthew Baillie Begbie in New Westminster, and Edward Cornwallis in Halifax, and renaming public institutions, buildings, and infrastructure, including Ryerson University in Toronto, the Davin School in Regina, the Langevin building in Ottawa, and the Langevin Bridge in Calgary.

The bronze statue of Edward Cornwallis, a military officer and first Lieutenant Governor of Nova Scotia who founded a British settlement at Halifax in 1749, was erected in Edward Cornwallis park in the south end of Halifax in 1931. The statue began generating controversy after Mi'kmaq Elder Daniel N. Paul's (1993) book highlighted the brutal details of Cornwallis's actions toward Mi'kmaq people during the establishment of Halifax on ancestral Mi'kmaq territory (Fraser, 2018). The controversy about Cornwallis's statue ebbed and flowed for 25 years, but it was not until April 2017 that Halifax Regional Council voted to form a panel to discuss the removal of the statue. The controversy came to national attention in July 2017, when a Canada Day protest at Cornwallis's statue organized by Indigenous activists and allies was crashed by five male members of 
"The Proud Boys," a far-right neo-fascist organization (HoSang \& Lowndes, 2019). The five men arrived at the protest singing "God Save the Queen" and waving a Red Ensign flag, the pre-1965 Canadian flag adopted by white supremacists as a symbol of Canada as a "white man's country." They accused protestors of disrespecting Cornwallis and argued with protestors about who owned the land Halifax is located on for 10 minutes before leaving.

Across Canada, some educators are addressing such controversies in their classrooms. For example, during the fall of 2017, teacher Temma Frecker of the Booker School in Port Williams, Nova Scotia, embarked on a six-week interdisciplinary project that asked Grade 6 to 8 students to research, debate, and arrive at a consensus solution to the Cornwallis statue controversy that they would present to the Halifax Regional Council. Frecker's goal was to help students understand that "certain perspectives are misrepresented or under-represented in Canadian history," and that "each version of history they hear depends on who's telling the story" (Corfu, 2018). Frecker wanted students "to feel empowered, whether it's talking about history or talking about whatever they're really passionate about" (Patil, 2019). The students researched the history of Cornwallis, the statue, and the relationship between Mi'kmaq people and British and French settlers. After proposing, debating, and negotiating potential solutions, the students decided that Cornwallis's statue should be removed from the pedestal and placed at ground level in a conversational circle with three new statues depicting individuals from three significant groups in Nova Scotian history. The students also proposed creating a plaque for the statues that described each person's contributions and challenges. The adviser for Indigenous community engagement for the City of Halifax praised the students for modelling the "collaboration and dialogue" he strives for in his work (Corfu, 2018). In recognition of her innovative project, Temma Frecker was awarded a 2018 Governor General's History Award for Excellence in Teaching.

The pedagogical approach that Temma Frecker used to teach about the Cornwallis controversy is a powerful example of the potential that commemoration controversies have for history education. In this article I argue that commemoration controversies should be an essential part of teaching and learning history in $\mathrm{K}-12$ schools because they are meaningful and relevant for students, they address civic education competencies central to history and social studies curricula in Canada, and they provide rich opportunities for advancing students' historical consciousness and historical thinking. In the final 
section of the article I describe how the six historical thinking concepts included in Seixas's (2017a) historical thinking framework can be used to invite students to think historically about commemorations. Before launching into the main argument, I briefly explain why commemorations have been contentious and divisive in the Canadian context.

\section{Contentious and Divisive}

Grever and Adriaansen (2017) argue that public controversies about collective memory and historical canons are a good indicator of problems and tensions within or between societies. In Canada, commemoration controversies have been particularly contentious because they focus on difficult histories that challenge commonly accepted versions of the past and feature oppositional forms of historical consciousness.

\section{Difficult History}

Education scholars use various terms to describe complex, complicated, and controversial histories, including: difficult knowledge (Britzman, 2000), the violent past (Cole, 2007), the sensitive past (van Boxtel et al., 2016), traumatic pasts (Psaltis et al., 2017), and difficult history (Epstein \& Peck, 2018; Gross \& Terra, 2018a). Epstein and Peck (2018) define difficult history as "historical narratives and other forms (learning standards, curricular frameworks) that incorporate contested, painful and/or violent events into regional, national or global accounts of the past" (p. 1). Gross and Terra (2018b) expand on this decision and identify five characteristics for further defining difficult history:

1. Difficult histories are central to a nation's history.

2. Difficult histories tend to refute broadly accepted versions of the past or stated national values.

3. Difficult histories may connect with questions or problems facing us in the present.

4. Difficult histories often involve violence, usually collective or state sanctioned.

5. Partly as the result of the other four conditions, difficult histories create disequilibria that challenge existing historical understandings. (p. 54) 
Gross and Terra's (2018b) conception of difficult history provides a useful framework for explaining why Canadian commemoration controversies have been contentious. Canadian commemoration controversies focus on historical events and people central to Canadian history, they challenge broadly accepted versions of Canadian history, they are connected to contemporary questions and issues, and they involve state-sanctioned violence.

Whether it be John A. Macdonald, Canadian Confederation, or Hector Langevin, the historical events and people at the heart of Canadian commemoration controversies are central to Canadian history and meet commonly identified criteria for determining an event or person's historical significance (Cercadillo, 2001; Counsell, 2004; Seixas, 1996). They were recognized as being important at the time they occurred or existed, the events and people's actions had profound consequences for many people over an extended period of time, and the people or events shaped the development of Canada.

The Canadian commemoration debates are connected to important questions and issues in the present, particularly demands to establish truth and reconciliation with Indigenous people. The final report of the Truth and Reconciliation Commission of Canada (TRC) calls to "remedy the gaps in historical knowledge that perpetuate ignorance and racism" (Truth \& Reconciliation Commission of Canada, 2015, p. 234). It urges making curriculum about Indian residential schools part of a broader history education that integrates First Nations, Inuit, and Métis voices, perspectives, and experiences; builds common ground between Aboriginal and non-Aboriginal peoples; rejects the racism embedded in colonial systems of education; and treats Aboriginal and Euro-Canadian knowledge systems with equal respect. The controversies about Canadian commemorations were initiated by Indigenous people and allies who challenged colonial historical narratives and reinterpreted Canada's history from Indigenous perspectives.

Each Canadian commemoration controversy also focuses on events or people that inflicted state-sanctioned violence against Indigenous people. For example,

- After repeated Mi'kmaq attacks on British settlers who invaded their territory, Edward Cornwallis issued the Scalping Proclamation in October 1749 that promised a bounty to anyone who killed a Mi'kmaq adult or child.

- In 1879, Nicholas Flood Davin wrote an influential government report that recommended that the federal government establish a system of 
government-funded, church-run Indian boarding schools. The Canadian government opened the first three Indian residential schools in 1883, and throughout the 113-year history of federally funded residential schools, 150,000 students attended 132 schools throughout Canada, more than 6,000 students died, and countless others suffered physical, emotional, and sexual abuse.

- In April 1864, 24 Tsilhqot'in warriors killed 19 men who entered their traditional territory without permission to build a road to the gold fields of the Cariboo Gold Rush. More than 100 colonial soldiers were sent to capture the warriors, but were unsuccessful. The conflict ended when Tsilhqot' in chiefs agreed to meet with colonial authorities to engage in peace talks after being promised immunity. When the five chiefs arrived for peace talks they were arrested and charged with murder. In September 1864, Chief Justice Matthew Baillie Begbie convicted the five chiefs of murder and sentenced them to death by hanging. Later that year a sixth chief was hanged in New Westminster.

Commemoration controversies also challenge broadly accepted understandings of Canadian history. Tim Stanley (2006) describes how Eurocentric grand narratives have become deeply embedded in the collective memory of many Canadians through various sources including mass media, school curricula, museums, monuments and plaques, public ceremonies, and popular history books. Grand narratives are "common sense" historical interpretations that explain and legitimate knowledge about the past and cement identity and membership in the "imagined community" of Canada. According to Stanley, the English-Canadian grand narrative begins with the arrival of the Europeans, disregards Indigenous people, and focuses on the progress of European settlement and nation-building. Confederation is the major turning point, and Indigenous people only re-enter the narrative when they challenge European progress. This teleological grand narrative starts in the present and makes European dominance seem inevitable and natural, it infantilizes people from Quebec, and excludes Indigenous people, Africans, Asians, and other minoritized groups.

For Murad Hemmadi (2018), maintaining a positive grand narrative about Canadian history is essential for those deeply invested in maintaining the status quo. The continued oppression of Indigenous people is baked into Canada's DNA. It is more than a 
series of tragic and unfortunate mistakes; the tragic nature of the oppression forces Canadians to move beyond simple apologies toward substantive reforms that address systemic injustices and oppression. However, there appears to be little common ground between defenders of the status quo and those who challenge nationalist, racist, and colonial grand narratives.

Supporters of the decision to remove Sir John A. Macdonald's statue from the entrance to Victoria City Hall highlighted Macdonald's role in implementing unjust and genocidal policies towards Indigenous people, including the potlatch ban, the Pass System, starvation of First Nations on federal reserves, the hanging of Louis Riel, and the creation of the residential school system (Boyko et al., 2017). Those who opposed the decision to remove the Macdonald statue emphasized Macdonald's role as a Father of Confederation, a principal architect of the Canadian state, and a visionary of a "Sea to Sea" nation united by a transcontinental railway (Boyko et al., 2017). We need to examine possible common ground between those who see Macdonald as the designer of genocidal policies toward Indigenous people, and supporters like Richard Gwyn whose 2007 book was entitled John A: The Man Who Made Us, or Conrad Black (2017) who referred to Macdonald as the far-sighted nation builder of "the only trans-continental, bicultural parliamentary confederation in the history of the world" (para. 3). For status quo defenders, accepting that Macdonald's policies and actions caused the genocide of Indigenous people delegitimizes the history of Canada and demands reorganization of the current social and political hierarchy. Arch-Macdonald defender Conrad Black (2017) recognized the stakes in the debate when he stated that "if the founder of the country is illegitimate, we all are" (para. 4).

\section{Opposing Types of Historical Consciousness}

Another reason why the Canadian commemoration controversies have been divisive is because they feature conflicting forms of historical consciousness. First introduced by German philosopher Hans-George Gadamer, historical consciousness has been further theorized and operationalized in ways that inform school curriculum and assessments in Germany, the Netherlands, Sweden, and other countries (Clark \& Peck, 2019a; Eliasson et al., 2015; Körber \& Meyer-Hamme, 2015; van Boxtel et al., 2016). Historical consciousness is the "complex interaction of interpretations of the past, perceptions of 
the present, and expectations towards the future" (Bracke et al., 2014, p. 23) and can be defined in terms of three interrelated aspects.

Firstly, historical consciousness focuses on the practical relationship between disciplinary knowledge and everyday life. Jorn Rüsen's (1989) disciplinary matrix theorizes this relationship by illustrating how the questions that drive historians' work arise from contemporary issues and needs, how historians use specialized theories and methodologies to create representations of the past in a variety of media, and how historians' representations are used by the larger culture to reshape thinking about the past and contemporary issues (Megill, 1994). Secondly, historical consciousness focuses on a person's orientation in time, including the mental operations used to make sense of temporal changes, orient practical life, and guide decision making (Rüsen, 2004). Thirdly, historical consciousness is expressed through narratives that are shared in various forms of historical culture including schools, historical scholarship, public history, media, family and community histories, heritage, and museums (Ahonen, 2005). These narratives play a central role in making sense of the past and its relationship to the present, providing a sense of orientation in time, and constructing identity and a sense of belonging in distinct communities (Clark \& Peck, 2019b; Lévesque \& Clark, 2018; Rüsen, 2002).

In order to understand how people use historical narratives to make sense of the past and inform decisions in the present and future, Jörn Rüsen (2004) created a typology consisting of four types of historical consciousness: traditional, exemplary, critical, and genetic (see Table 1). The four types of historical consciousness are not mutually exclusive and can be read as a sequence of increasingly sophisticated modes of historical consciousness along a continuum (Rüsen, 2012a, 2012b).

\section{Table 1}

Jorn Rüsen's Four Types of Historical Consciousness

\begin{tabular}{ll}
\hline \multicolumn{1}{c}{ Type } & \multicolumn{1}{c}{ Description } \\
\hline Traditional & $\begin{array}{l}\text { The past provides us with permanent, obligatory, and } \\
\text { prescriptive ways of living that should be followed in the } \\
\text { present. }\end{array}$ \\
Exemplary & $\begin{array}{l}\text { The past provides examples and lessons that are instructive } \\
\text { for contemporary actions and beliefs. }\end{array}$
\end{tabular}




\begin{tabular}{ll}
\hline \multicolumn{1}{c}{ Type } & \multicolumn{1}{c}{ Description } \\
\hline Critical & $\begin{array}{l}\text { The past is no longer relevant for contemporary circum- } \\
\text { stances, values, and needs. Counternarratives are used to } \\
\text { deconstruct commonly accepted narratives and break conti- } \\
\text { nuities between past and present. }\end{array}$ \\
Genetic & $\begin{array}{l}\text { The past is different than today. The purpose is neither to } \\
\text { maintain nor disrupt continuity between past and present, } \\
\text { but to historicize differences across time to make decisions } \\
\text { and take actions that construct a better future. }\end{array}$ \\
\hline
\end{tabular}

Arguments about Canadian commemoration controversies can be classified into two oppositional groups: one that includes traditional and exemplary forms of historical consciousness, and one that contains critical and genetic types. Traditional and exemplary modes of historical consciousness assume continuity between past and present (Chapman, 2019). A traditional form of historical consciousness presupposes that historical narratives are fixed, preordained, and provide us with permanent and obligatory ways of living that should be repeated in the present (Lee, 2004). The focus is on preserving and venerating the past in order to establish continuity between past and present, and to strengthen common identity through the invocation of "a debt of remembrance to forebears, victims of injustice, founders, protectors, and leaders who contributed or sacrificed" (Seixas \& Clark, 2004, p. 155). Exemplary historical consciousness assumes that the past provides rules of human conduct that remain valid in the present, and past events are treated as cases or examples that provide lessons for the present that should be followed (Lee, 2004).

Those who espouse traditional and exemplary forms of historical consciousness support keeping historical commemorations intact to preserve continuity between past and present. In traditional and exemplary modes of historical consciousness, any challenge to existing commemorations is tantamount to erasing and destroying the past. Underlying these types of historical consciousness are facile understandings about the nature of history. History is seen as an objective record of things that should not be altered and rewritten. It is considered to be both desirable and possible for historians to write a single true "objective" historical narrative free from personal values and beliefs (Maza, 2017). In an article condemning the Elementary Teachers' Federation of Ontario's (ETFO) motion that recommended the removal of Sir John A. Macdonald's name from all Ontario 
schools, columnist John Ivison (2017) said that history is "a record of things past that should not be altered or rewritten in Orwellian fashion by some Ministry of Truth to suit its own political ends" (para. 2). Counternarratives that challenge dominant narratives are labelled as politically correct, revisionist, or presentist. No differentiation is made between the past and present, and the preservation of commemorations is valued because those commemoratives were created by people in the past. For example, Conservative Member of Parliament Erin O'Toole criticized the ETFO's decision as an example of presentism. Jason Kenney, the leader of the United Conservative Party of Alberta, called the decision to remove John A. Macdonald's statue from Victoria City Hall "historical vandalism," and Andrew Scheer, the leader of the federal Conservative Party, criticized the decision for allowing "political correctness to erase our history" (Hemmadi, 2018, para. 12).

The opposing position in the commemoration debates features critical and genetic types of historical consciousness. The critical mode highlights discontinuity between the past and the present by critiquing traditional and exemplary historical narratives for having immoral origins and consequences, and for being antithetical to the needs and values of the present (Chapman, 2019; Lee, 2004). Counternarratives are used to deconstruct commonly accepted narratives and rupture links between the past and present so that the past "loses its power for present-day orientation" (Rüsen, 2004, p. 75). For those "whom history oppresses," a critical approach seeks liberation from the past through the destruction of hegemonical narratives and the sites and symbols that preserve them by producing new commemorations to orient present-day life and create a new world "without the burden of the past" (Seixas \& Clark, 2004, p. 156). Genetic historical consciousness focuses on "historicizing" and studying commemorations as products of their time (Seixas \& Clark, 2004, p. 158). A genetic historical consciousness recognizes "the fundamental and radical fact that we make history, that we are immersed in history, that we are historical beings" (Ricœur \& Thompson, 1981, p. 274). The goal of critical and genetic types of historical consciousness is neither to maintain nor disrupt continuity between the past and the present, but to historicize historical evidence and draw lessons that can be used to construct a better future.

The critical and genetic types of historical consciousness feature understandings about the nature of history that are oppositional to traditional and exemplary types. History is understood to be a construction that imposes coherence on the residues of the past 
that make it into history (Bruner, 2005). As Rüsen (2012b) states, "The past itself is not yet history" and only "becomes history by the activity of the human mind" (p. 47). The notion of historical objectivity is rejected and it is understood that while historical narratives are grounded in evidence and argument, no account is definitive (Novick, 1988). Historical narratives respond to questions and problems posed in the present, they are constructed for specific purposes and particular audiences, they exist in time and change with time, they are plural and variable, and they are shaped by the assumptions, identities, and subjectivities of the people who construct them (Chapman, 2017). As beliefs, ideas, and values change, historians ask different questions about the past, and revise previous interpretations. All historical interpretations are revisionist in that they are shaped by conditions and priorities in the present, and history might be best described as "a conversation about the past in the present" (Maza, 2017, p. 201).

Thus, critical and genetic forms of historical consciousness help us understand that commemorations are interpretations created by individuals and groups for specific purposes after the event occurred or the person was alive. Matthew Sears (2018) points out that statues, monuments, and other commemorations were not created to record history, but to shape perceptions of history in particular ways and for particular purposes, including glorification of an event, political leader, party, or ideology. Commemorations provide more evidence about the attitudes, values, and beliefs of those who created them than they provide about the historical event or person being commemorated. James Loewen (1999) illustrates how the historical interpretations presented by public commemorations are often inaccurate, incomplete, mono-perspectival, focus on positive aspects and omit negative aspects, and are discriminatory toward minoritized groups including women, people of colour, and Indigenous people. Thus, people who ascribe to a genetic type of historical consciousness understand that the removal of a statue or the renaming of a building is a reinterpretation of history, not an erasure or demolition.

\section{Why Commemoration Controversies Are Important for History Education}

Except for Boerhout and van Driel (2013) and Kello (2016), few scholars have researched how commemoration controversies are taught in school history classrooms. 
There is a rich body of research literature focused on how controversial issues are taught in social studies classrooms, but most studies focus on contemporary political, economic, and social topics rather than historical ones. Research on controversial issues has found that many teachers are reluctant to teach about controversial issues because of a "complex terrain of institutional and curricular constraints; societal discourse and expectations; national, group, and individual histories; local, state, and national policies; personal beliefs; and multiple and overlapping identities involving ethnicity and religion" (Ho et al., 2017, p. 323).

Gross and Terra (2018a) argue that there is much at stake if difficult histories like commemoration controversies are left unexplored in history classrooms, but highlight potential risks that teaching about these topics presents, including reinforcing ethnic, religious, and cultural divisions, undermining social cohesion, and challenging one of the traditional functions of history education in nation-states - reinforcing a shared understanding of a national past. In the following section I argue that commemoration controversies should be taught and learned about in history and social studies classrooms because of their challenging and complicated nature. Commemoration controversies have the potential to make history meaningful and relevant for students, they address key civic competencies central to history and social studies curricula, and they offer generative opportunities for advancing students' historical consciousness and historical thinking.

\section{Make History Meaningful and Relevant}

Van Straaten et al. (2016) define relevance in history education as "allowing students to recognize and experience what history has to do with themselves, with today's society, and their general understanding of human existence" (p. 482). History teaching standards and curricula commonly identify making history relevant as a goal, but most focus on outlining what students should learn about the past and few explicit connections between the past, present, and future are made (Van Straaten et al., 2016). It is assumed that students will be able to apply their knowledge to the present and future by virtue of studying the past, but research suggests that many students think history is irrelevant to their lives, or if they do think it is important, they struggle to explain why (Harris, 2010; Haydn \& Harris, 2010; Kello, 2016; Levstik \& Barton, 2011). Many students struggle to make connections between past, present, and future, and offer presentist perspectives because 
they think the past does not inform the present (Barton, 2008; Foster et al., 2008; Shemilt, 2009; van Drie \& van Boxtel, 2008). Furthermore, there is little pedagogical literature or empirical research available that offers guidance to teachers about how to make history relevant for students.

Commemoration controversies have the potential to be meaningful and relevant for students because they are connected to students' daily lives and experiences outside of school and they address important contemporary issues and problems. Whether students realize it or not, history plays an important role in their daily lives and when students see, hear, and participate in discussion about commemorations this connection is made more explicit. Almost every community has examples of historic sites, monuments, plaques, street names, and museums that have been, currently are, or could be controversial in the future (Sears, 2020). Even if historical sites or monuments have not been, or are not currently controversial, teachers can invite students to analyze and assess the appropriateness of commemorations, identify unknown people and events deserving of commemoration, rename an historical building, rewrite a commemorative plaque, or redesign a commemoration in their local community. For example, archaeologist Joanne Hammond started an online project called \#rewriteBC to decolonize historical plaques along British Columbia's highways that challenge dominant narratives by creating counternarratives that include Indigenous perspectives and histories (“Archaeologist 'decolonizes' B.C.'s Road Signs via Photoshop," 2017).

Commemoration controversies also have the potential to make learning history more intellectually active and meaningful. A. B. Hodgetts's landmark 1968 study on the state of civic and history education in Canada lamented the "bland consensus version of history," the emphasis on memorization rather than deep learning, and the failure to help students establish connections between the past and present (Hodgetts, 1968, p. 24). Although there have not been any large-scale studies of Canadian history education since then, some research suggests that the history education described by Hodgetts persists today (Osborne, 2011). Students are less likely to be interested in the study of history if they remain passive receivers of disconnected historical facts rather than active investigators into history's dynamic nature (Stipp et al., 2017). Inviting students to make reasoned judgements in open-ended investigations of historical controversies is inherently more meaningful than being asked to learn predetermined conclusions. Brown (1996) found that "the pursuit into the past of questions that students could see reflections of in 
their own lives - and questions, moreover, to which there were no easy answers - would deepen students' understanding of themselves" (p. 272). Furthermore, the active construction of knowledge, including linking new knowledge to existing knowledge and applying knowledge to different contexts, may lead to the effective construction of new knowledge (Van Straaten et al., 2016).

\section{Address Key Civic Competencies}

History and citizenship education have been inextricably linked since history was first included in Canadian school curricula at the end of the 19th century. In English- and French-speaking Canada, history was included in the curriculum because it was believed to contribute to the development of a common national identity, values, patriotism, and sense of national pride (Osborne, 2011). By the end of the 1990s, the nation-building approach was replaced in history and social studies curricula by an approach that promoted participatory, activist, and democratic citizenship. According to Alan Sears (2011), there is broad international scholarly consensus about the importance of an activist and participatory conception of citizenship as the focus for civic education in democratic states. This conception of citizenship defines ideal citizens as those who are "knowledgeable about contemporary society and the issues it faces; disposed to work toward the common good; supportive of pluralism; and skilled at taking action to make their communities, nation, and the world a better place" (p. 353). Helping students establish their personal identity is an important part of the participatory approach, which includes helping students see themselves as individuals with a personal past shaped by the society and communities they are part of, as well as the development of their values, opinions, and beliefs (Van Straaten et al., 2016). Participatory citizenship is often defined in curricula in terms of civic competencies - knowledge, skills, values, and dispositions needed to participate in civic life. Despite important differences in the articulation of citizenship competencies in provincial and territorial history and social studies curricula, Sears (2014) argues that most curricula emphasize the following knowledge, skills, and dispositions:

- Knowledge of key democratic citizenship concepts: rule of law, justice, responsible government, consent of the governed, freedoms, rights and responsibilities, individual and collective agency. 
- Skills: investigating open-ended questions, debates, and issues of historical and contemporary importance; critical thinking; decision making and problem solving; gathering, analyzing, and synthesizing evidence from multiple sources; assessing multiple perspectives, collaboration; critical media literacy; effective communication.

- Values and dispositions: fair-mindedness, empathy, humility, circumspection, respect for diverse values and points of view.

Inviting students to participate in debates about commemoration controversies, and explicitly teaching the knowledge, skills, and values needed to articulate an informed opinion has the potential to address the civic competencies central to history and social studies curricula in Canada in a meaningful way. Temma Frecker's students exhibited many of the civic competencies outlined above during their investigation of the Edward Cornwallis statue controversy.

There is a growing body of evidence from civics education research that suggests that pedagogical approaches that invite student voice and active engagement in community issues have a significant impact in fostering active citizenship (Torney-Purta $\&$ Amadeo, 2013). A recent review of more than 100 studies from around the world that used International Association for the Evaluation of Educational Achievement (IEA) civics data found that an open classroom climate is essential for fostering positive outcomes including civic knowledge, expected political behaviour, and supportive attitudes regarding gender, ethnic, and immigrant rights (Knowles et al., 2018). These findings are supported by McAvoy and Hess (2014) who found that students who are regularly invited to engage in discussion of controversial political issues describe being more engaged in class and feeling more confident in their ability to participate in discussions, demonstrate increased political knowledge, display more interest in politics and follow the news more regularly, are more likely to engage in political discussions with people they disagree with, and are more interested in listening to opinions different than their own.

\section{Developing Historical Thinking and Historical Consciousness}

Commemoration controversies also provide rich opportunities for advancing students' historical consciousness and historical thinking because they require students to use their historical knowledge to make informed decisions about the present and future. Historical 
consciousness and historical thinking are two influential ideas in the theory and practice of history education, and although the terms are often used interchangeably, they are different but interrelated. Historical consciousness focuses on how people make sense of the past and use history to orient themselves in the present and future. The central goal of historical consciousness is to help students acquire the competencies to orientate "independent actions as an emancipated member of society" (Körber, 2015, p. 4). Körber (2015) conceptualizes historical consciousness as a set of four competencies that are defined as "capabilities, dispositions, and skills necessary to undertake the required operations. Historical consciousness then is a competence- a competence to think historically” (p. 19; see also Körber \& Meyer-Hamme, 2015). For Körber, historical thinking is essential for the development of historical consciousness, but it is not an educational end itself (Lévesque \& Clark, 2018, p. 124). Catherine Duquette's (2015) research suggests a strong correlation between the development of historical consciousness and students' capacity with the concepts and processes of historical thinking (Seixas, 2017b). These findings are supported by Grever (2019) who states that "historical thinking and reasoning seem to be one of the roads to develop historical consciousness as a competence, involving verbally expressed, cognitive dealings with the past and embodied expressions of how people experience, use, and perform the past" (p. 226).

Historical thinking focuses on teaching students to "interpret and assess evidence from the past in order to understand, evaluate, and construct narrative accounts about the past" (Stipp et al., 2017, p. 3). The structure and form of historical thinking is conceptualized using the notion of "second-order historical concepts," which Lee and Ashby (2000) define as disciplinary (or procedural) concepts that shape "the way we go about doing history" (p. 199). Rather than measuring students' accumulation of factual knowledge, students' increasingly sophisticated ability to apply second-order concepts like change, significance, evidence, and consequence to historical content defines their progress in learning history (Seixas, 2017b).

In Canada, Peter Seixas's (2006) influential framework, comprised of six second-order historical thinking concepts, has been included in provincial and territorial social studies and history curricula and numerous textbooks, books, and classroom resources. Seixas (2017a) explains that his framework draws from British, American, and German theories of historical thinking and historical consciousness, and was conceptualized to be "intelligible and communicable to teachers and students, yet generative enough 
to guide explorations of fundamental epistemological and ontological problems of history" (p. 598). For Seixas (2017a), the six historical thinking concepts closely resemble second-order procedural concepts that shape history as a form of knowledge, but they also function as generative problems, tensions, or difficulties inherent in doing history that require "comprehension, negotiation, and, ultimately, an accommodation that is never a complete solution" (p. 597). Thus, the goal is for students to understand and apply the concepts to historical content with increasing skill in order to deepen their understanding of both historical knowledge (i.e., Canadian history) and how historical knowledge is made and remade (McGregor, 2017). Asking students to make informed judgements about commemoration controversies has the potential to support the development of their historical consciousness because it requires them to use their understanding of substantive content and historical thinking concepts to make decisions about how to respond in the present (Van Straaten et al., 2016). In the section below I describe how each of the six second-order concepts from Seixas's historical thinking framework can be used to frame questions that invite students to think historically about commemorations.

\section{An Historical Thinking Approach to Commemoration Controversies}

There are six second-order historical thinking concepts in Seixas's (2017a) framework, including historical significance, evidence, continuity and change, cause and consequence, historical perspectives, and the ethical dimension. All six concepts are relevant for analyzing commemoration controversies, but three concepts in particular-evidence, historical significance, and the ethical dimension - are particularly germane. In the section below I provide a brief description of each historical thinking concept, explain how it can be applied to commemoration controversies, and outline a series of questions I developed that can be used by educators to invite students to think historically about commemoration controversies. Given the large number of questions provided, it would be unreasonable to expect students to respond to all of the questions when analyzing a commemoration controversy. Instead, educators should select the concept(s) and question(s) most relevant to their goals and purposes and the commemoration being investigated. 


\section{Evidence}

Evidence focuses on interpreting and analyzing primary and secondary sources to critique and construct historical arguments and narratives (Stipp et al., 2017). Analyzing monuments, statues, and other commemorations of historical events or people is complicated because they have ambiguous meanings that are open to interpretation (Parkes, 2017) and function as both primary and secondary sources. Commemorations have their own histories, distinct from the historical event or person being commemorated, and can be analyzed as primary sources that provide evidence about the values, attitudes, and motivations of the people who decided to commemorate an event or person. Commemorations were created after the event or person being commemorated occurred or existed and offer narrative interpretations of an event or person, that although abbreviated, can be interpreted and analyzed like other secondary sources, including books and documentary films. For example, the statue of Sir John A. Macdonald that was removed from Victoria City Hall was placed there in 1982, 91 years after his death.

The following questions invite students to analyze historical commemorations as sources of historical evidence:

- Sourcing: What type of commemoration is being investigated? When and where was the commemoration created? Who created the commemoration and who provided financial support and permission to create it? Why was the commemoration created? Where was the commemoration located and why was it placed there?

- Contextualizing: What was happening at the time the commemoration was created?

- Close reading: What interpretations about the event or person being commemorated are being made? What symbols, artefacts, images, structures, or words are used to communicate these claims? What does the commemoration reveal about the values, beliefs, and attitudes of the people or groups who created the commemoration?

- Corroboration: Is the interpretation of the historical event or person offered by the commemoration justifiable given the historical evidence? Do other primary and secondary sources provide evidence that support or refute the interpretation being made about the event, person, or group being commemorated? 


\section{Historical Significance}

Historical significance focuses on making decisions about which events, people, or groups from the past should be remembered, studied, and taught. Thus, historical significance is central to commemoration controversies because commemorations are the end result of decisions made about historical significance. Decisions about who or what should be commemorated, what should be said about the person or event and what should be left out, and where the commemoration should be located all focus on aspects of historical significance. If students do not consider why some people and events are commemorated and not others, they may simply accept that all events or people that have been commemorated in the past are historically significant. The following questions invite students to assess the historical significance of commemorations:

- Is the event, person, or group being commemorated historically significant?

- Was the event, person, or group being commemorated recognized as being important when the event occurred, or when the people or groups were alive?

- Did the event, person, or group being commemorated cause change and have deep consequences for many people over time?

- Does the event, person, or group being commemorated highlight enduring or emerging issues in history or contemporary life?

- For which groups are the event, person, or group being commemorated historically significant? How does the historical significance of the event, person, or group being commemorated vary from group to group?

- In which larger historical narrative(s) is the event, person, or group being commemorated regularly included?

\section{Continuity and Change}

The analysis of continuity and change invites students to examine what has changed and stayed the same over time, and the degree to which those changes led to progress or decline for different people. Continuity and change are important to commemoration controversies because changing interpretations of the historical events and people who have been commemorated have fuelled the debates. This set of questions invites students 
to consider the ways that interpretations of people and events being commemorated have changed and stayed the same over time, while also considering whether the changes that resulted from the commemorated event or person's actions can be seen as progress or decline for different groups. The following questions invite students to identify examples of continuity and change in historical commemorations over time.

- Have interpretations of the event, person, or group being commemorated changed or stayed the same over time?

- Were the changes that resulted from the commemorated event, person, or group's actions positive or negative? For which groups were the changes positive, and for which groups were they negative?

\section{Cause and Consequence}

The cause and consequence historical thinking concept focuses on who and what influenced historical events to happen, and what the effects or results of those events were. When thinking historically about commemoration controversies students can be invited to assess the role the person or event being commemorated played in causing other events to occur, and the impact the event and person's actions had on people. The following questions invite students to analyze the causes and consequences of the events being commemorated.

- What historical events were caused by the person or event being commemorated?

- What impact did the event or the actions of the person or group being commemorated have? Were the consequences positive or negative?

\section{Historical Perspectives}

The historical perspectives concept focuses on helping students better understand the beliefs, values, worldviews, and practices that shaped people's lives and actions in the past. One of the most challenging aspects of thinking historically is trying to understand what life was like in a time and place that was often very different from the present. Our historical understandings are shaped by our current concerns, beliefs, and values, and a key aspect of historical perspectives is remaining mindful of potential differences 
between our worldviews and those of people in the past. Contemporary attitude toward Indigenous people is different in many than the attitudes of John A. Macdonald and many of his contemporaries. At the same time, it is also important to remember that not everyone shared the same attitudes, beliefs, and ideas. While Sir John A. Macdonald's attitudes towards Indigenous people were shared by many Euro-Canadians at the time, they were opposed by Indigenous people and many others. When teaching students to think historically about commemoration controversies it is important to help students understand the diversity of attitudes about the events or actions of the people being commemorated at the time they occurred, when the commemoration was created, and today. The following questions invite students to consider the different historical perspectives about the historical commemoration.

- What did people think about the person or event being commemorated at the time they existed or the event occurred?

- What did people think about the person or event being commemorated when the commemoration was created?

- What do people think about the commemorated person or event today?

\section{The Ethical Dimension}

The ethical dimension focuses on making ethical judgements about whether the actions of historical actors in the past were justified, which individuals or groups deserve credit or blame for their actions, and what obligations those in the present owe to victims, heroes, and others who took actions in the past. Ethics focuses on the "relationship between moral stances, that is, what individuals or communities take to be right/wrong or good/ bad and the ongoing contemplation of what we could or should do" (Milligan et al., 2018, p. 453). Ethical judgements imbue the study of history with meaning and expand students' historical consciousness by helping them learn from past wrongdoings, judge the past more fairly, and deal more effectively with present-day ethical dilemmas (Seixas \& Morton, 2013).

Commemoration controversies raise complex and important ethical questions about the past, present, and future that are not easily reconcilable. According to Barton and Levstik (2004), these types of ethical questions are central to participatory democracy "because the decisions we make in the public sphere are invariably about our vision of 
the common good, and about what we hope to achieve together as a society" (p. 92). Similarly, James Loewen (1999) explains that "the commemorations a community decides to create on its landscape sums up its view of the past and influences its possible futures" ( $p$. 40). Leaving the name of a controversial person on a building or the statue of a person in place makes a powerful statement to future generations about which people and events are worthy of remembrance. The decisions we make about who and what gets commemorated and what narratives we tell about them have real consequences for our society.

When teaching students to make ethical judgements it is important that they consider the historical context, distinguish between historical and contemporary ethical standards, and consider the extent to which a person or group was in a position to influence the outcome of an event. The following questions can be used to invite students to analyze the ethical dimension of commemoration controversies:

- Should the event, person, or group be commemorated and memorialized given its historical legacy? Should the commemoration be kept as is, revised, or removed?

- Is the event, person, or group's historical legacy aligned with the values and beliefs of the community where the commemoration is located?

- Does the commemoration of the event, person, or group negatively affect individuals or groups in the community where the commemoration is located?

- Were the person or group's actions acceptable given the values, attitudes, and beliefs that existed at the time? Would the person or group's actions be acceptable today given contemporary values, attitudes, and beliefs?

- Was the person or group commemorated actually responsible for the historical events for which they are being commemorated?

\section{Final Thoughts}

Recent Canadian commemoration controversies have brought the study of history into the present and provided history and social studies teachers with a unique opportunity to make history relevant and meaningful for students, address civic competencies that are 
central to history and social studies curricula in Canada, and foster the development of students' historical consciousness and historical thinking. Inviting students to make decisions about difficult histories that are highly relevant to contemporary political and social concerns is essential for the education of historically informed and ethically engaged citizens. Commemoration controversies require students to interrelate the past, present, and future, handle complex ethical dilemmas, and consider the implications of historical ethical dilemmas for the present and future (Grever, 2019). In this way, commemoration controversies have the potential to align the goals, purposes, and methods of citizenship education, historical consciousness, and historical thinking. It is my hope that this article encourages educators to take up the study of historical commemorations in history and social studies classes, and provides guidance about how they might invite students to approach commemorations in ways that nurture historical thinking and historical consciousness. 


\section{References}

Ahonen, S. (2005). Historical consciousness: A viable paradigm for history education? Journal of Curriculum Studies, 37(6), 697-707.

Archaeologist “decolonizes” B.C.'s road signs via Photoshop. (2017, February 14). CBC News. https://www.cbc.ca/news/canada/british-columbia/ archaeologist-decolonizes-b-c-s-road-signs-via-photoshop-1.3981211

Barton, K. C. (2008). Research on students' ideas about history. In L. S. Levstik \& C. A. Tyson (Eds.), Handbook of research in social studies education (pp. 239-258). Routledge.

Barton, K. C., \& Levstik, L. S. (2004). Teaching history for the common good. Lawrence Erlbaum Associates.

Black, C. (2017, August 24). Our society is under attack-From vilifying John A. to antifa. National Post. https://nationalpost.com/opinion/ conrad-black-our-society-is-under-attack-from-vilifying-john-a-to-antifa

Boerhout, L., \& van Driel, B. (2013). Memory walk: An interaction-oriented project to interrogate contested histories. Intercultural Education, 24(3), 211-221.

Boyko, J., King, H., MacSkimming, R., \& Milnes, A. (2017, June 19). Visionary patriot or hateful embarrassment? The John A. Macdonald debate. The Globe and Mail. https://www.theglobeandmail.com/opinion/sir-john/article22362438/

Bracke, S., Flaving, C., Köster, M., \& Zulsdorf-Kersting, M. (2014). History education research in Germany. In M. Köster, H. Thunemann, \& M. Zulsdorf-Kersting (Eds.), Researching history education (pp. 9-55). Wochenschau Verlag.

Britzman, D. P. (2000). If the story cannot end: Deferred action, ambivalence and difficult knowledge. In R. I. Simon, S. Rosenberg, \& C. Eppert (Eds.), Between hope and despair: Pedagogy and the remembrance of historical trauma (pp. 27-56). Rowman \& Littlefield.

Brown, R. H. (1996). Learning how to learn: The Amherst Project and history education in the schools. The Social Studies, 87(6), 267-273. 
Bruner, J. S. (2005). Past and present as narrative constructions. In J. Straub (Ed.), Narrative, identity, and historical consciousness (Vol. 3, pp. 23-43). Berghahn Books.

Cercadillo, L. (2001). Significance in history: Students' ideas in England and Spain. In A. K. Dickinson, P. Gordon, \& P. Lee (Eds.), International review of history education (pp. 116-145). Routledge.

Chapman, A. (2017). Historical interpretations. In I. Davies (Ed.), Debates in history teaching (pp. 100-112). Routledge.

Chapman, A. (2019). "Orientation to the Past": Some reflections on historical consciousness research from England. In A. Clark \& C. L. Peck (Eds.), Contemplating historical consciousness: Notes from the field (pp. 32-45). Berghahn Books.

Clark, A., \& Grever, M. (2018). Historical consciousness: Conceptualizations and educational applications. In S. A. Metzger \& L. McArthur Harris (Eds.), The Wiley international handbook of history teaching and learning (pp. 177-201). John Wiley \& Sons.

Clark, A., \& Peck, C. L. (Eds.). (2019a). Contemplating historical consciousness: Notes from the field. Berghahn Books.

Clark, A., \& Peck, C. L. (2019b). Historical consciousness: Theory and practice. In A. Clark \& C. L. Peck (Eds.), Contemplating historical consciousness: Notes from the field (pp. 1-15). Berghahn Books.

Cole, E. A. (Ed.). (2007). Teaching the violent past: History education and reconciliation. Rowman \& Littlefield.

Corfu, N. (2018, January 11). Kids propose solution to Cornwallis statue woes. CBC News. https://www.cbc.ca/news/canada/nova-scotia/ edward-cornwallis-statue-halifax-park-students-solution-1.4483005

Counsell, C. (2004). Looking through a Josephine-Butler-shaped window: Focusing pupils' thinking on historical significance. Teaching History, 114, 30-33. 
Duquette, C. (2015). Relating historical consciousness to historical thinking through assessment. In K. Ercikan \& P. Seixas (Eds.), New directions in assessing historical thinking (pp. 51-63). Routledge.

Eliasson, P., Alvén, F., Yngvéus, C. A., \& Rosenlund, D. (2015). Historical consciousness and historical thinking reflected in large-scale assessment in Sweden. In K. Ercikan \& P. Seixas (Eds.), New directions in assessing historical thinking (pp. 171-182). Routledge.

Epstein, T., \& Peck, C. L. (Eds.). (2018). Teaching and learning difficult histories in international contexts: A critical sociocultural approach. Routledge.

Foster, S., Ashby, R., Lee, P., \& Howson, J. (2008). Usable historical pasts: A study of students'frameworks of the past. ESRC. https://gtr.ukri.org/ projects?ref=RES-000-22-1676

Fraser, T. (2018, March 13). Edward Cornwallis, public memory, and Canadian nationalism. Active History. http://activehistory.ca/2018/03/ edward-cornwallis-public-memory-and-canadian-nationalism/

Grever, M. (2019). Why historical consciousness? In A. Clark \& C. L. Peck (Eds.), Contemplating historical consciousness: Notes from the field (pp. 224-232). Berghahn Books.

Grever, M., \& Adriaansen, R.-J. (2017). Historical culture: A concept revisited. In M. Carretero, S. Berger, \& M. Grever (Eds.), Palgrave handbook of research in historical culture and education (pp. 73-89). Palgrave Macmillan.

Gross, M. H., \& Terra, L. (2018a). Introduction: What makes difficult history difficult. In M. H. Gross \& L. Terra (Eds.), Teaching and learning the difficult past: Comparative perspectives (pp. 1-8). Routledge.

Gross, M. H., \& Terra, L. (2018b). What makes difficult history difficult? Phi Delta Kappan, 99(8), 51-56.

Gwyn, R. J. (2007). John A: The man who made us: The life and times of John A. Macdonald. Random House Canada.

Harris, R. (2010). Citizenship and history: Uncomfortable bedfellows. In I. Davies (Ed.), Debates in history teaching (pp. 186-196). Routledge. 
Haydn, T., \& Harris, R. (2010). Pupil perspectives on the purposes and benefits of studying history in high school: A view from the UK. Journal of Curriculum Studies, 42(2), 241-261.

Hemmadi, M. (2018, August 18). What fights about "erasing” history are really about. Maclean's. https://www.macleans.ca/opinion/ what-fights-about-erasing-history-are-really-about/

Ho, L.-C., McAvoy, P., Hess, D., \& Gibbs, B. (2017). Teaching and learning about controversial issues and topics in the social studies. In M. M. Manfra \& C. M. Bolick (Eds.), The Wiley handbook of social studies research (pp. 319-335). John Wiley \& Sons.

Hodgetts, A. B. (1968). What culture? What heritage? A study of civic education in Canada. Ontario Institute for Studies in Education.

HoSang, D. M., \& Lowndes, J. E. (2019). Producers, parasites, patriots: Race and the new right-wing politics of precarity. University of Minnesota Press.

Ivison, J. (2017). John Ivison: Even John A. Macdonald isn’t safe from a foolish revisionism that never ends. National Post. http://nationalpost.com/news/politics/ john-ivison-even-john-a-macdonald-isnt-safe-from-a-foolish-revisionism-that$\underline{\text { never-ends }}$

Kello, K. (2016). Sensitive and controversial issues in the classroom: Teaching history in a divided society. Teachers and Teaching, 22(1), 35-53.

Knowles, R. T., Torney-Purta, J., \& Barber, C. (2018). Enhancing citizenship learning with international comparative research: Analyses of IEA civic education datasets. Citizenship Teaching \& Learning, 13(1), 7-30.

Körber, A. (2015). Historical consciousness, historical competencies - and beyond? Some conceptual development within German history didactics. PeDOCS, 1-56. https:// www.pedocs.de/frontdoor.php?source_opus $=10811$

Körber, A., \& Meyer-Hamme, J. (2015). Historical thinking, competencies, and their measurement: Challenges and approaches. In K. Ercikan \& P. Seixas (Eds.), New directions in assessing historical thinking (pp. 89-101). Routledge. 
Lee, P. (2004). "Walking backwards into tomorrow": Historical consciousness and understanding history. International Journal of History Learning, Teaching and Research, 4(1), 69-114.

Lee, P., \& Ashby, R. (2000). Progression in historical understanding among students ages 7-14. In P. N. Stearns, P. Seixas, \& S. S. Wineburg (Eds.), Knowing, teaching, and learning history (pp. 199-222). New York University Press.

Lévesque, S., \& Clark, P. (2018). Historical thinking: Definitions and educational applications. In S. A. Metzger \& L. M. Harris (Eds.), The Wiley international handbook of history teaching and learning (pp. 119-148). John Wiley \& Sons.

Levstik, L. S., \& Barton, K. C. (2011). Doing history: Investigating with children in elementary and middle school (4th ed.). Routledge.

Loewen, J. W. (1999). Lies across America: What our historic sites get wrong. New Press.

Maza, S. C. (2017). Thinking about history. University of Chicago Press.

McAvoy, P., \& Hess, D. E. (2014). The political classroom: Evidence and ethics in democratic education. Taylor and Francis.

McGregor, H. E. (2017). One classroom, two teachers? Historical thinking and Indigenous education in Canada. Critical Education, 8(14), 1-18.

Megill, A. (1994). Jörn Rüsen's theory of historiography between modernism and rhetoric of inquiry. History and Theory, 33(1), 39-60.

Milligan, A., Gibson, L., \& Peck, C. L. (2018). Enriching ethical judgments in history education. Theory and Research in Social Education, 46(3), 449-479.

Nora, P., \& Kritzman, L. D. (1996). Realms of memory: Rethinking the French past. Columbia University Press.

Novick, P. (1988). That noble dream: The "objectivity question" and the American historical profession. Cambridge University Press.

Osborne, K. (2011). Teaching Canadian history: A century of debate. In P. Clark (Ed.), New possibilities for the past: Shaping history education in Canada (pp. 55-80). University of British Columbia Press. 
Parkes, R. (2017, October 19). Are monuments history? Public History Weekly. https:// public-history-weekly.degruyter.com/5-2017-34/are-monuments-history/

Patil, A. (2019, January 26). Cornwallis statue project nets Port Williams teacher prestigious award. CBC. https://www.cbc.ca/news/canada/nova-scotia/ temma-frecker-cornwallis-statue-project-booker-school-1.4994436

Paul, D. N. (1993). We were not the savages: A Micmac perspective on the collision of European and Aboriginal civilizations. Nimbus.

Psaltis, C., Carretero, M., \& Cehajic-Clancy, S. (2017). History education and conflict transformation: Social psychological theories, history teaching and reconciliation. Palgrave Macmillan.

Ricœur, P., \& Thompson, J. B. (1981). Hermeneutics and human sciences: Essays on language, action, and interpretation. Cambridge University Press.

Rüsen, J. (1989). The development of narrative competence in historical learning-An ontogenetic hypothesis concerning moral consciousness. History and Memory, 1(2), 35-59.

Rüsen, J. (2002). Western historical thinking: An intercultural debate. Berghahn Books.

Rüsen, J. (2004). Historical consciousness: Narrative structure, moral function, and ontogenetic development. In P. Seixas (Ed.), Theorizing historical consciousness (pp. 63-85). University of Toronto Press.

Rüsen, J. (2012a). Forming historical consciousness: Towards a humanistic history didactics. Antíteses, 5(10), 519-536.

Rüsen, J. (2012b). Tradition: A principle of historical sense-generation and its logic and effect in historical culture. History and Theory, 51, 45-59.

Sears, A. (2011). Historical thinking and citizenship education: It is time to end the war. In P. Clark (Ed.), New possibilities for the past: Shaping history education in Canada (pp. 344-364). University of British Columbia Press.

Sears, A. (2014). Measuring what matters: Citizenship domain. People for Education. https://peopleforeducation.ca/wp-content/uploads/2017/06/MWM CitizenshipPaper.pdf 
Sears, A. (2020). Public history goes to school. In R. Case \& P. Clark (Eds.), Learning to inquire in history, geography, and social studies: An anthology for secondary teachers (pp. 11-13). The Critical Thinking Consortium.

Sears, M. A. (2018, October 9). Monuments aren’t museums, and history suffers when we forget that. Maclean's. https://www.macleans.ca/opinion/ monuments-arent-museums-and-history-suffers-when-we-forget-that/

Seixas, P. (1996). Conceptualizing the growth of historical understanding. In D. R. Olson \& N. Torrance (Eds.), The handbook of education and human development (pp. 765-783). Blackwell Publishers.

Seixas, P. (2006). Benchmarks of historical thinking: A framework for assessment in Canada (pp. 1-12). Centre for the Study of Historical Consciousness, University of British Columbia. http://historicalthinking.ca/sites/default/files/files/docs/ Framework EN.pdf

Seixas, P. (2017a). A model of historical thinking. Educational Philosophy and Theory, 49(6), 593-605.

Seixas, P. (2017b). Historical consciousness and historical thinking. In M. Carretero, S. Berger, \& M. Grever (Eds.), Palgrave handbook of research in historical culture and education (pp. 59-72). Palgrave Macmillan.

Seixas, P., \& Clark, P. (2004). Murals as monuments: Students' ideas about depictions of civilization in British Columbia. American Journal of Education, 110(2), $146-171$.

Seixas, P., \& Morton, T. (2013). The big six historical thinking concepts. Nelson Education.

Shemilt, D. (2009). Drinking an ocean and pissing a cupful: How adolescents make sense of history. In L. Symcox \& A. Wilschut (Eds.), National history standards: The problem of the canon and the future of history teaching (pp. 141-209). Information Age Publishing.

Stanley, T. (2006). Whose public? Whose memory? Racisms, grand narratives, and Canadian history. In R. W. Sandwell (Ed.), To the past: History education, public memory and citizenship in Canada (pp. 32-49). University of Toronto Press. 
Stipp, S., Gibson, L., Denos, M., Case, R., \& Miles, J. (2017). Teaching historical thinking: Revised and expanded edition. The Critical Thinking Consortium.

Torney-Purta, J., \& Amadeo, J.-A. (2013). The contributions of international large-scale studies in civic education and engagement. In M. von Davier, E. Gonzalez, I. Kirsch, \& K. Yamamoto (Eds.), The role of international large-scale assessments: Perspectives from technology, economy, and educational research (pp. 87-114). Springer Netherlands.

Truth \& Reconciliation Commission of Canada. (2015). Honouring the truth, reconciling for the future: Summary of the final report of the Truth and Reconciliation Commission of Canada. Truth and Reconciliation Commission of Canada.

van Boxtel, C., Grever, M., \& Klein, S. (2016). Sensitive pasts: Questioning heritage in education. Berghahn Books.

van Drie, J., \& van Boxtel, C. (2008). Historical reasoning: Towards a framework for analyzing students' reasoning about the past. Educational Psychology Review, 2, 87-110.

Van Straaten, D., Wilschut, A., \& Oostdam, R. (2016). Making history relevant to students by connecting past, present and future: A framework for research. Journal of Curriculum Studies, 48(4), 479-502. 